\title{
Angiopoietins, abdominal aortic aneurysm and atherosclerosis
}

\author{
Alexandra F. Trollope and Jonathan Golledge \\ The Vascular Biology Unit, School of Medicine and Dentistry, James Cook University, Douglas \\ Campus, Townsville, QLD 4811, Australia
}

\begin{abstract}
Abdominal aortic aneurysm (AAA) and atherosclerosis are common causes of mortality and morbidity in an aging population. Angiogenesis is believed to contribute to the development and progression of these diseases. Angiopoietins (angpts) are known to be important regulators of angiogenesis. Angpts can also influence inflammation and have been shown to possess both proatherosclerotic and atheroprotective effects. This review explores the potential roles that the angpts play in the development and progression of AAA and atherosclerosis.
\end{abstract}

\section{Keywords}

Abdominal aortic aneurysm; Atherosclerosis; Angiopoietins

\section{Introduction}

Cardiovascular diseases (CVDs) remain the major cause of global morbidity and mortality. This review focuses on two of the most common CVDs abdominal aortic aneurysm (AAA) and athero-thrombosis. AAA and atherosclerosis have a strong association causing controversy over whether they are separate diseases [1]. The diseases share common risk factors which contribute to their development such as smoking, age and obesity [2,3]. They also have some similar pathological characteristics such as inflammation, proteolysis, apoptosis and angiogenesis. Angiogenesis is the formation of new blood vessels from preexisting blood vessels and is a prominent feature in both diseases [4-7]. The regulation of angiogenesis is not yet fully understood however the angiopoietins (angpts) appear to play an important role and as a result have begun to receive considerable interest.

Angpts are ligands which bind to the transmembrane receptor Tie-2 and possibly Tie-1. These receptors are essential for the correct formation and development of blood vessels [8]. The Tie receptors are part of the receptor tyrosine kinase (RTK) family that is separated into two main sub-groups according to their amino acid composition: The vascular endothelial growth factor (VEGF) family that includes Flt-4 and Flk-1/KDR and a second family that includes Tek (Tie-2) and Tie (Tie-1) receptors [9]. Angiogenesis is thought to depend on a balance of activators and inhibitors that regulate the 'angiogenic switch' [10].

\section{Angiopoietins}

The first angpt to be discovered was angpt 1 which is secreted by pericytes, mesenchyme and vascular smooth muscle cells (VSMCs) of the developing vasculature and is thought to stabilize the formation of newly formed blood vessels [11,12]. Angpts utilise the same

(C) 2010 Elsevier Ireland Ltd. All rights reserved.

"Corresponding author. Tel.: +61 74796 1417; fax: +61 74796 1401. Jonathan.Golledge@ @cu.edu.au (J. Golledge). 
binding domain for the Tie receptors and were initially thought to be exclusive for these receptors, however, angpt 1 and 2 have been shown to interact with other receptors, including integrins [13]. This suggests that the angpts could be involved in mediating cell adhesion or migration through integrins independent of the Tie-2 receptor. Angpt 2 was discovered by sequence homology to angpt 1 [14] and is secreted by endothelial cells (ECs) and VSMCs. Both angpt 1 and 2 have been shown to be secreted by human cord blood $\mathrm{CD} 34^{+}$cells and are necessary for EC differentiation and proliferation, respectively [15]. The role of angpt 2 in the vasculature appears to be influenced by vascular endothelial growth factor (VEGF), in the absence of VEGF angpt 2 destabilizes the interaction between ECs and their support cells causing plasma leakage (the escape of plasma and plasma proteins, along with white blood cells, from the vessel), and promotes vascular regression. In the presence of VEGF, angpt 2 promotes angiogenesis by allowing ECs to be more responsive to VEGF mediated cell proliferation which is necessary for ECs repair and turn over [16,17]. Angpt 1 and VEGF are thought to have a complementary effect on blood vessel growth which could be due to both ligands being able to activate the receptor Tie-2. Angpt 1 is a well known for activating the Tie-2 receptor while there is still some controversy over whether angpt 2 activates or represses the Tie- 2 receptor which is discussed later. The angpts expression profiles in human tissues are also diverse for example angpt 2 is expressed in the ovaries, uterus and placenta while angpt 1 is expressed in the prostate, skeletal muscle, small intestine, heart, and areas of the brain. These data suggest that angpt 2 expression is largely restricted in adults to sites of active vascular remodeling while angpt 1 is more widespread [14]. It must also be mentioned that some interspecies orthologs also exist such as angpt 3 in mouse and angpt 4 in human. Very little is known about these ligands, however, angpt 3 is thought to act as an agonist while angpt 4 exerts an antagonist effect at the Tie- 2 receptor. Their expression patterns also differs with angpt 3 being expressed throughout the body but angpt 4 only detected in lung [18].

\subsection{Effect of angpts at the Tie-2 receptor}

Angpt 2 was originally shown to be a competitive antagonist of angpt 1 binding to the Tie-2 receptor in ECs. Recent evidence has established that both angpt 1 and 2 are capable of activating the Tie-2 receptor in NH 3T3 fibroblasts while in ECs only angpt 1 is capable of activating the Tie-2 receptor, suggesting that there is functional discrimination between the two angpts and that angpt 2 in particular functions in a context-dependent manner [14]. The first direct evidence that angpt 2 has agonist effects on the Tie- 2 receptor was provided in experiments using human umbilical vascular endothelial cells (HUVECs) conducted by Teichert-Kuliszewska et al. Consistent with these findings a recent study indicated that in the absence of angpt 1, angpt 2 acts as an agonist for the Tie- 2 receptor, however, in the presence of angpt 1 it acts as an antagonist in HUVECs [19]. Davis et al. showed that dimers of the receptor binding domain of angpt 1 and 2 could activate Tie- 2 receptors on fibroblasts but not in ECs. While tetramers of angpt 1 but not angpt 2 could activate the receptor in ECs and fibroblasts [20]. Overall it appears that angpt 2 can activate the Tie-2 receptor in a time and context specific manner and acts as a partial agonist, while angpt 1 appears to be amore effective Tie-2 activator. Although the angpts can form larger complexes between themselves in order to activate their receptors, it is not known whether they interact with other proteins in vivo.

\subsection{Knockout studies}

In order to investigate the function of angpts and their receptors mice deficient in these proteins ("knock outs") have been constructed and their phenotypes examined as summarised in Table 1 [9,21-23]. Homozygous null or dominant negative transgenic mice for the Tie-2 receptor are deficient in ECs and exhibit cardiac abnormalities [21]. Tie-1 deficient mice have a reduction in EC structural integrity [22]. Angpt 1 deficient mice show 
defects in heart development and a reduction in vascular complexity [9], while angpt 2 deficiency impairs lymphatic and blood vessel development [23]. A trait that was similar to all knockouts was the occurrence of premature death.

\subsection{Tie receptor signalling}

The Tie-2 receptor is expressed mainly on hematopoietic stem cells (HSCs), ECs and more recently found to be expressed on monocytes [24,25]. The Tie-2 receptor is not exclusively associated with the angpts. VEGF has been shown to bind to the Tie- 2 receptor and is thought to initiate EC survival and migration [26]. The Tie-1 receptor has not been explored to the same extent as the Tie-2, for example there is not much known about its ligands. However colony stimulating factor-1 is thought to activate the receptor, which then signals via the PI3K/akt pathways [27]. The Tie- 1 and 2 receptors are activated by autophosphorylation which induces a signalling cascade, through the akt pathway that is essential to mediate the survival of ECs (see Fig. 1) [28]. The akt signalling pathway is known to control several cellular functions in the cardiovascular system. The Tie-1 and Tie-2 receptors have an added dimension in that they themselves can heterodimerise to form a Tie-2:Tie-1 complex [29] and this structure is thought to be important for blood vessel remodeling and development [30]. A study by Hansen et al. demonstrated that angpt 2 could bind to both the Tie-2 receptor and the Tie-2:Tie-1 receptor complex [31]. Angpt 1 preferentially binds to Tie-2. The differential binding of angpt 1 and angpt 2 is mediated by the Tie-1 receptor $[31,32]$. Tie- 1 and 2 functions become even more complicated in that they can be cleaved to give a soluble form (sTie-1 and sTie-2) [33]. Proteolytic cleavage of the Tie-1 receptor's ectodomain leaves the membrane bound endodomain unable to bind to its ligand [30,34]. Findley and colleagues showed that the Tie-2 extracellular domain is also shed due to the action of proteases and that sTie- 2 is capable of binding to either angpt 1 or 2 and inhibiting ligand binding signalling [35]. These findings suggest that sTie- 2 is functioning as a natural antagonist to membrane bound Tie-2. Tie-1 and Tie-2 cleavage can also be induced by a number of other mechanisms, such as the action of VEGF via the PI3Kinase (phosphatidylinositol 3-kinases) and akt pathway [35]. These data give insight into the complexity of the mechanisms involved in the regulation of the Tie-2 signalling pathway.

\section{Pathological features of AAA and atherosclerosis and the relevance of angpts}

AAA and atherosclerosis have some similar pathological features as summarised in Table 2 . Angpt 1 and 2 have been shown to promote mechanisms likely to have both protective and permissive roles in the development and progression of athero-thrombosis and AAA (Table 3 ). There are various pathways and mechanisms involved which lead to the different pathological features displayed by both diseases (Fig. 1). The angpts have been recognised mostly for their involvement in angiogenesis and inflammation two pathological features common to AAA and atherosclerosis.

\subsection{Angpts in angiogenesis}

The angpts regulate angiogenesis by activating or inhibiting the Tie-2 receptor as shown by knock out mouse models [9,21-23] and in mice which over express angpt 1 [36]. Angiogenesis is also relevant in inflammation; the production of new vessels supports a greater influx of inflammatory cells. The Tie-2 receptor has been shown to induce signal transducer and activator of the transcription factors (STATs) 1, 2, 3 and 5 [37,38]. STAT 3 is an important factor in initiating angiogenesis and is an angiogenic mediator in vascular formation in the postnatal heart [39]. 


\subsection{Angpts in inflammation}

Inflammation is thought to play a critical role in the development and progression of AAA and atherosclerosis [40-42]. During the early stages of atheroma development circulating monocytes migrate from the blood into the intima where they develop into tissue specific macrophages. The macrophages express scavenger receptors that bind to and internalise oxidised lipids which have been deposited in the fatty streak giving rise to foam cells [43]. These foam cells secrete pro-inflammatory cytokines which stimulate further accumulation of inflammatory cells and also release proteolytic enzymes, such as matrix metalloproteases (MMPs) which can promote extracellular matrix degradation [44]. Biopsies taken from large AAAs demonstrate transmural infiltration of a variety of inflammatory cells, including macrophages, lymphocytes, neutrophils and mast cells [45]. This chronic inflammation is associated with high concentrations of cytokines and proteolytic enzymes which have been linked to medial destruction [46-47]. Angpt 1 has been shown to promote vessel stabilization during angiogenesis, inhibit vascular permeability and exerts anti-inflammatory effect via the Tie-2 receptor $[11,48,49]$. Angpt 1 has also been shown to counteract the inflammatory effects of VEGF by reducing the induction of adhesion molecules such as ICAM-1 and VCAM-1 on ECs causing a reduction in leukocyte adhesion and subsequent inflammation [50,51]. While angpt 1 has been shown to have a protective effect against inflammation, angpt 2 has been shown to have the opposite effect and promote inflammation. Osteoprotegrin (OPG) has been shown to upregulate angpt 2 in HUVECs thereby sensitising the cells to TNF- $\alpha$ [52]. TNF- $\alpha$ is a pleiotropic pro-inflammatory cytokine which stimulates adhesion molecule upregulation and promotes cell apoptosis through the inhibition of survivin and activation of caspase [53]. Fiedler et al. investigated the effect of angpt 2 deficiency on inflammation in mice [54]. Angpt $2^{-/-}$mice showed no inflammatory response to infection. While recombinant angpt 2 (rAngpt 2) recovered the ability of angpt ${ }^{-/-}$mice to mount an acute inflammatory response [54]. The in vitro part of this study used siRNA to knock down angpt 2 in ECs resulting in inhibition of TNF- $\alpha$ induced ICAM-1 expression. The ability of TNF- $\alpha$ to upregulate ICAM- 1 could be rescued by application of exogenous angpt 2 [54]. Increases in adhesion molecules on ECs enhance leukocyte infiltration into the arterial wall and promotes inflammation [54]. Angpt 2 has also been shown to have other pro-inflammatory effects, such as chemoattraction of monocytes and macrophages which express the Tie-2 receptor [55] this mechanism would therefore encourage the migration of leukocytes into the arterial wall. Interestingly the angpts appear to be differentially expressed on leukocytes with human neutrophils and platelets expressing angpt 1 but not angpt 2 [56] while ECs express angpts 1 and 2 [12,57,58]. Both angpts have been shown to directly activate ECs and neutrophils via the Tie-2 receptor [59]. The Tie-1 receptor's role is less understood. A recent study suggested that over-expressing the receptor in ECs promoted adhesion molecule upregulation and so facilitated inflammation [27]. The fact that the Tie receptors can heterodimerise and that Tie-1 is thought to mediate the binding of angpt 1 and 2 to Tie- 2 makes interpreting results more challenging. Furthermore the notion that sTie-2 has an antagonistic effect on the membrane bound Tie-2 is supported by an experiment were mice administered with sTie- 2 showed inhibition of the immune response. sTie- 2 promoted a reduction in TNF- $\alpha$ induced ICAM expression resulting in reduced adhesion of leukocytes to ECs [54] and thereby inhibited inflammation. Most current evidence suggests that angpt 2 promotes but angpt 1 inhibits inflammation, supporting the theory that angpt 1 and 2 have opposing roles.

\section{Angiopietins role(s) in AAA and atherosclerosis}

Based on the discussion above it can be appreciated that angpts have the potential to alter pathological processes critical to atherosclerosis and AAA as summarised in Table 3. Despite this the role of angpts in CVD has received relatively little study. 


\subsection{Evidence from animal studies}

Despite the evidence outlined above suggesting that angpt 2 has a number of proatherosclerotic effects a recent study by Ahmed and colleagues supported an atheroprotective effect of angpt 2 [60]. In this study $\mathrm{ApoE}^{-/-}$mice were administered an angpt 2 adenovirus (AdEV) which led to a reduction in atherosclerosis severity assessed by plaque lesion size [60]. There was also a decrease in CD11b-positive monocyte/ macrophages and malondialdehydelysine (MDA2) (a marker for oxidised LDL) within the atheroma in response to the AdEV [60]. Related in vitro studies in HUVECs suggested angpt 2 reduced LDL oxidation formation which can lead to the formation of foam cells in an nitric oxide (NO) dependent manner [60]. A recent study has suggested that angpt 1 has atheroprotective properties by upregulating the expression of apelin. Apelin is a molecule implicated in protection against atherosclerosis by antagonising the pro-atherosclerotic affects of angiotensin II in ApoE ${ }^{-/-}$mice (see Fig. 1) [61-63]. Apelin is a peptide mainly released from ECs and stimulates a G-coupled receptor APJ which is located within myocardial and some VSMCs [64]. Kidoya et al. demonstrated that apelin expression was increased in a time dependent fashion after stimulation with angpt 1 . This ability of angpt 1 to upregulate apelin was also seen in vivo in transgenic mice over-expressing angpt 1 (Angpt $1 / \mathrm{Tg}$ mice). Studies conducted by Leeper et al. supports the idea that apelin is involved in preventing vascular disease especially AAA. The investigators reported that apelin stimulated a reduction in aortic diameter, preservation of aortic elastin and collagen, and a significant reduction in adhesion molecules and inflammatory cell infiltrate compared to litter mate controls. The investigators concluded that apelin had anti-inflammatory effect which inhibited AAA formation [62]. Angpt 1 has also been shown to protect against the development of arteriosclerosis in cardiac allografts, by reducing the influx of leukocytes into the graft and thereby reducing inflammation and also permeability [65]. Hauer et al. induced T-cell mediated immunity against Tie-2 expressing in $\mathrm{LDLR}^{-/-}$mice and demonstrated that the vaccinated mice had reduced aortic lesions, intimal expansion, and adventitial neovessel formation. Plaques in vaccinated mice also had a more stable appearance with a significant increase in collagen content. These results suggest that vaccination against the Tie-2 receptor lead to smaller and more stable atherosclerotic plaques [66]. Controversially the double mouse knockout model Akt1 ${ }^{-/-} \mathrm{ApoE}^{-/-}$, demonstrated that the loss of akt1 (isoform of akt) a molecule activated downstream of Tie-2 activation (see Fig. 1) led to increased inflammatory mediators and reduced endothelial nitric oxide synthase (eNOS) phosphorylation within the vessel wall [67]. eNOS is involved in many physiological processes such as neovascularisation, platelet aggregation, vascular permeability and the interaction between leukocytes and ECs [68].

\subsection{Evidence from human studies}

Atherosclerotic plaque microvessels have been associated with unstable and rupture prone plaques, but the mechanisms behind their formation are poorly understood. In human atherosclerotic plaques with high microvessel density greater concentrations of angpt 2 than angpt 1 were found in association with high concentrations of MMP 2 [69]. Cross-sectional studies which have compared circulating levels of angpts, in patients with or without CVDs have been summarised in Table 4. There appears to be a strong correlation between CVD and increased levels of angpt 2 and sTie-2. The concentration of circulating sTie- 2 has been reported to be greater in patients with congestive heart failure (CHF) and hypertension, by comparison to healthy controls [70]. A study by Freestone and colleagues demonstrated that in patients with atrial fibrillation, levels of plasma angpt 2 correlated with vWF, which could suggest a link between endothelial damage and angpt 2 [71]. Other conditions such as peripheral arterial disease (PAD), acute and chronic CHF and diabetes were also associated with elevated circulating levels of plasma angpt $2[35,70]$. Plasma concentrations of angpt 2 have also been related to concurrently prescribed medications, with no association 
demonstrated with angiotensin II receptor blockers (ARBs) [72]. These data suggest that angpts, could be involved in either the progression of CVD or that elevated concentrations are a consequence of CVD, e.g. elevated in an effort to minimise atherosclerosis progression. It has been suggested that angpt 2 could be used as a circulating biomarker of not only angiogenesis but also for critically ill patients [72,73] and more recently the progression of CVD [74]. sTie-2 has also received interest as a possible biomarker of PAD [35].

\section{Conclusions and future directions for research}

Good evidence now implicates angpts in vascular formation and angiogenesis. Further work is required to better understand the pathological role of angpts in vascular diseases. For example the evidence from animal models suggesting that angpt 2 is protective against atherosclerosis does not fit with the findings that angpt 2 can promote inflammation and angiogenesis, both mechanisms implicated in atheroma development and progression. Further studies are needed to clarify the clinical importance of this pathway in terms of targets for therapy or biomarkers of these diseases.

\section{Acknowledgments}

This work was supported by funding from the National Health and Medical Research Council, Australia (project grant number 540405). Jonathan Golledge holds a Practitioner's Fellowship from the National Health and Medical Research Council, Australia (grant number 431503).

\section{References}

1. Golledge J, Norman P. Atherosclerosis and abdominal aortic aneurysm: cause, response, or common risk factors? Arterioscler Thromb Vasc Biol 2010;30:1075-1077. [PubMed: 20484703]

2. Golledge J, Muller J, Daugherty A, Norman P. Abdominal aortic aneurysm: pathogenesis and implications for management. Arterioscler Thromb Vasc Biol 2006;26:2605-2613. [PubMed: 16973970]

3. Solberg LA, Strong JP. Risk factors and atherosclerotic lesions. A review of autopsy studies. Atherosclerosis 1983;3:187-198.

4. Silverstein RL, Nachman RL. Angiogenesis and atherosclerosis. Circulation 1999;100:783-785. [PubMed: 10458710]

5. Kahlon R, Shapero J, Gotlieb AI. Angiogenesis in atherosclerosis. Can J Cardiol 1992;8:60-64. [PubMed: 1377591]

6. Thompson MM, Jones L, Nasim A, Sayers RD, Bell PRF. Angiogenesis in abdominal aortic aneurysms. Eur J Vasc Endovasc Surg 1996;11:464-469. [PubMed: 8846184]

7. Choke E, Cockerill G, Dawson J, et al. The role of angiogenesis in abdominal aortic aneurysm rupture. Atherosclerosis 2008;199:463-464.

8. Mustonen T, Alitalo K. Endothelial receptor tyrosine kinases involved in angiogenesis. J Cell Biol 1995;129:895-898. [PubMed: 7538139]

9. Suri C, Jones PF, Patan S, et al. Requisite role of angiopoietin-1, a ligand for the TIE2 receptor, during embryonic angiogenesis. Cell 1996;87:1171-1180. [PubMed: 8980224]

10. Hanahan D, Folkman J. Patterns and emerging mechanisms of the angiogenic switch during tumorigenesis. Cell 1996;9:353-364. [PubMed: 8756718]

11. Davis S, Aldrich TH, Jones PF, et al. Isolation of angiopoietin-1, a ligand for the TIE2 receptor, by secretion-trap expression cloning. Cell 1996;87:1161-1169. [PubMed: 8980223]

12. Sundberg C, Kowanetz M, Brown LF, Detmar M, Dvorak HF. Stable expression of angiopoietin-1 and other markers by cultured pericytes: phenotypic similarities to a subpopulation of cells in maturing vessels during later stages of angiogenesis in vivo. Lab Invest 2002;84:387-401. [PubMed: 11950897] 
13. Dallabrida SM, Ismail NS, Pravda EA, et al. Integrin binding angiopoietin-1 monomers reduce cardiac hypertrophy. FASEB J 2008;22:3010-3023. [PubMed: 18502941]

14. Maisonpierre PC, Suri C, Jones PF, et al. Angiopoietin-2, a natural antagonist for Tie2 that disrupts in vivo angiogenesis. Science 1997;277:55-60. [PubMed: 9204896]

15. Hildbrand P, Cirulli V, Prinsen RC, et al. The role of angiopoietins in the development of endothelial cells from cord blood CD34+ progenitors. Blood 2004;104:2010-2019. [PubMed: 15213103]

16. Holash J, Wiegand SJ, Yancopoulos GD. New model of tumor angiogenesis: dynamic balance between vessel regression and growth mediated by angiopoietins and VEGF. Oncogene 1999;18:5356-5362. [PubMed: 10498889]

17. Lobov IB, Brooks PC, Lang RA. Angiopoietin-2 displays VEGF-dependent modulation of capillary structure and endothelial cell survival in vivo. Proc Natl Acad Sci USA 2002;99:1120511210. [PubMed: 12163646]

18. Valenzuela DM, Griffiths JA, Rojas J, et al. Angiopoietins 3 and 4: diverging gene counterparts in mice and humans. Proc Natl Acad Sci USA 1999;96:1904-1909. [PubMed: 10051567]

19. Teichert-Kuliszewska K, Maisonpierre PC, Jones N, et al. Biological action of angiopoietin-2 in a fibrin matrix model of angiogenesis is associated with activation of Tie2. Cardiovasc Res 2001;49:659-670. [PubMed: 11166279]

20. Davis S, Papadopoulos N, Aldrich TH, et al. Angiopoietins have distinct modular domains essential for receptor binding, dimerization and superclustering. Nat Struct Biol 2003;10:38-44. [PubMed: 12469114]

21. Dumont DJ, Gradwohl G, Fong GH, et al. Dominant-negative and targeted null mutations in the endothelial receptor tyrosine kinase, tek, reveal a critical role in vasculogenesis of the embryo. Genes Dev 1994;16:1897-1909. [PubMed: 7958865]

22. Sato TN, Tozawa Y, Deutsch U, et al. Distinct roles of the receptor tyrosine kinases Tie-1 and Tie-2 in blood vessel formation. Nature 1995;376:40-74.

23. Gale NW, Thurston G, Hackett SF, et al. Angiopoietin-2 is required for postnatal angiogenesis and lymphatic patterning, and only the latter role is rescued by angiopoietin-1. Dev Cell 2002;3:411423. [PubMed: 12361603]

24. De Palma M, Venneri MA, Naldini L. In vivo targeting of tumor endothelial cells by systemic delivery of lentiviral vectors. Hum Gene Ther 2003;14:1193-1206. [PubMed: 12908970]

25. De Palma M, Venneri MA, Galli R, et al. Tie2 identifies a hematopoietic lineage of proangiogenic monocytes required for tumor vessel formation and a mesenchymal population of pericyte progenitors. Cancer Cell 2005;3:211-226. [PubMed: 16169466]

26. Singh H, Milner CS, Aguilar Hernandez MM, Patel N, Brindle NP. Vascular endothelial growth factor activates the Tie family of receptor tyrosine kinases. Cell Signal 2009;21:1346-1350. [PubMed: 19376222]

27. Chan B, Yuan HT, Ananth Karumanchi S, Sukhatme VP. Receptor tyrosine kinase Tie-1 overexpression in endothelial cells upregulates adhesion molecules. Biochem Biophys Res Commun 2008;371:475-479. [PubMed: 18448073]

28. DeBusk LM, Hallahan DE, Lin PC. Akt is a major angiogenic mediator downstream of the Ang1/ Tie2 signaling pathway. Exp Cell Res 2004;298:167-177. [PubMed: 15242771]

29. Saharinen P, Kerkelä K, Ekman N, et al. Multiple angiopoietin recombinant proteins activate the Tie1 receptor tyrosine kinase and promote its interaction with Tie2. J Cell Biol 2005;169:239-243. [PubMed: 15851516]

30. Tsiamis AC, Morris PN, Marron MB, Brindle NP. Vascular endothelial growth factor modulates the Tie-2:Tie-1 receptor complex. Microvasc Res 2002;63:149-158. [PubMed: 11866538]

31. Hansen TM, Singh H, Tahir TA, Brindle NP. Effects of angiopoietins-1 and -2 on the receptor tyrosine kinase Tie 2 are differentially regulated at the endothelial cell surface. Cell Signal 2010;22:527-532. [PubMed: 19922791]

32. Seegar TC, Eller B, Tzvetkova-Robev D, et al. Tie1-Tie2 interactions mediate functional differences between angiopoietin ligands. Mol Cell 2010;37:643-655. [PubMed: 20227369] 
33. Reusch P, Barleon B, Weindel K, et al. Identification of a soluble form of the angiopoietin receptor TIE-2 released from endothelial cells and present in human blood. Angiogenesis 2001;4:123-131. [PubMed: 11806244]

34. Yabkowitz R, Meyer S, Black T, et al. Inflammatory cytokines and vascular endothelial growth factor stimulate the release of soluble tie receptor from human endothelial cells via metalloprotease activation. Blood 1999;93:1969-1979. [PubMed: 10068670]

35. Findley CM, Mitchell RG, Duscha BD, Annex BH, Kontos CD. Plasma levels of soluble Tie2 and vascular endothelial growth factor distinguish critical limb ischemia from intermittent claudication in patients with peripheral arterial disease. J Am Coll Cardiol 2008;52:387-393. [PubMed: 18652948]

36. Suri C, McClain J, Thurston G, et al. Increased vascularization in mice overexpressing angiopoietin-1. Science 1998;282:468-471. [PubMed: 9774272]

37. Calvi C, Dentelli P, Pagano M, et al. Angiopoietin 2 induces cell cycle arrest in endothelial cells: a possible mechanism involved in advanced plaque neovascularization. Arterioscler Thromb Vasc Biol 2004;24:511-518. [PubMed: 14726409]

38. Korpelainen EI, Kärkkäinen M, Gunji Y, Vikkula M, Alitalo K. Endothelial receptor tyrosine kinases activate the STAT signaling pathway: mutant Tie-2 causing venous malformations signals a distinct STAT activation response. Oncogene 1999;18:1-8. [PubMed: 9926914]

39. Chen Z, Han ZC. STAT3: a critical transcription activator in angiogenesis. Med Res Rev 2008;28:185-200. [PubMed: 17457812]

40. Brophy CM, Reilly JM, Smith GJ, Tilson MD. The role of inflammation in nonspecific abdominal aortic aneurysm disease. Ann Vasc Surg 1991;5:229-233. [PubMed: 2064915]

41. Rijbroek A, Moll FL, Dijk HA, Meijer R. Inflammation of the abdominal aortic aneurysm wall. Eur J Vasc Surg 1994;8:41-46. [PubMed: 8307214]

42. Rehm JP, Grange JJ, Baxter BT. The formation of aneurysm. Sem Vasc Surg 1998;11:193-202.

43. Libby P. Inflammatory mechanisms: the molecular basis of inflammation and disease. Nutr Rev 2007;65:S140-S146. [PubMed: 18240538]

44. Libby P. Inflammation in atherosclerosis. Nature 2002;420:868-874. [PubMed: 12490960]

45. Golledge J, Norman PE. Pathophysiology of abdominal aortic aneurysm relevant to improvements in patients' management. Curr Opin in Cardiol 2009;24:532-538.

46. Shimizu K, Mitchell RN, Libby P. Inflammation and cellular immune responses in abdominal aortic aneurysms. Arterioscler Thromb Vasc Biol 2006;26:987-994. [PubMed: 16497993]

47. Weintraub NL. Understanding abdominal aortic aneurysm. N Eng J Med 2009;361:1114-1116.

48. Hughes DP, Marron MB, Brindle NP. The antiinflammatory endothelial tyrosine kinase Tie2 interacts with a novel nuclear factor-kappaB inhibitor ABIN-2. Circ Res 2003;92:630-636. [PubMed: 12609966]

49. Thurston G. Role of angiopoietins and Tie receptor tyrosine kinases in angiogenesis and lymphangiogenesis. Cell Tissue Res 2003;314:61-68. [PubMed: 12915980]

50. Gamble JR, Drew J, Trezise L, et al. Angiopoietin-1 is an antipermeability and anti-inflammatory agent in vitro and targets cell junctions. Circ Res 2000;87:603-607. [PubMed: 11009566]

51. Kim I, Moon SO, Park SK, Chae SW, Koh GY. Angiopoietin-1 reduces VEGF-timulated leukocyte adhesion to endothelial cells by reducing ICAM-1, VCAM-1, and E-selectin expression. Circ Res 2001;89:477-479. [PubMed: 11557733]

52. Mangan SH, Van Campenhout A, Rush C, Golledge J. Osteoprotegerin upregulates endothelial cell adhesion molecule response to tumor necrosis factor-alpha associated with induction of angiopoietin-2. Cardiovasc Res 2007;76:494-505. [PubMed: 17706953]

53. Reed JC. The survivin saga goes in vivo. J Clin Invest 2001;108:965-969. [PubMed: 11581297]

54. Fiedler U, Reiss Y, Scharpfenecker M, et al. Angiopoietin-2 sensitizes endothelial cells to TNFalpha and has a crucial role in the induction of inflammation. Nat Med 2006;12:235-239. [PubMed: 16462802]

55. Murdoch C, Tazzyman S, Webster S, Lewis CE. Expression of Tie-2 by human monocytes and their responses to angiopoietin-2. J Immunol 2007;178:7405-7411. [PubMed: 17513791] 
56. Neagoe PE, Brkovic A, Hajjar F, Sirois MG. Expression and release of angiopoietin-1 from human neutrophils: intracellular mechanisms. Growth Factors 2009;27:335-344. [PubMed: 19919521]

57. Nishishita T, Lin PC. Angiopoietin 1, PDGF-B, and TGF-beta gene regulation in endothelial cell and smooth muscle cell interaction. J Cell Biochem 2004;91:584-593. [PubMed: 14755687]

58. Li JJ, Huang YQ, Basch R, Karpatkin S. Thrombin induces the release of angiopoietin-1 from platelets. Thromb Haemost 2001;85:204-206. [PubMed: 11246533]

59. Lemieux C, Maliba R, Favier J, et al. Angiopoietins can directly activate endothelial cells and neutrophils to promote proinflammatory responses. Blood 2005;15:1523-1530. [PubMed: 15498854]

60. Ahmed A, Fujisawa T, Niu XL, et al. Angiopoietin-2 confers atheroprotection in apoE-/- mice by inhibiting LDL oxidation via nitric oxide. Circ Res 2009;104:1333-1336. [PubMed: 19461044]

61. Chun HJ, Ali ZA, Kojima Y, et al. Apelin signaling antagonizes Ang II effects in mouse models of atherosclerosis. J Clin Invest 2008;118:3343-3354. [PubMed: 18769630]

62. Leeper NJ, Tedesco MM, Kojima Y, et al. Apelin prevents aortic aneurysm formation by inhibiting macrophage inflammation. Am J Physiol Heart Circ Physiol 2009;296:H1329-H1335. [PubMed: 19304942]

63. Kidoya H, Ueno M, Yamada Y, et al. Spatial and temporal role of the apelin/APJ system in the caliber size regulation of blood vessels during angiogenesis. EMBO J 2008;27:522-534. [PubMed: 18200044]

64. Chen MM, Ashley EA, Deng DX, et al. Novel role for the potent endogenous inotrope apelin in human cardiac dysfunction. Circulation 2003;23:1432-1439. [PubMed: 12963638]

65. Nykänen AI, Krebs R, Saaristo A, et al. Angiopoietin-1 protects against the development of cardiac allograft arteriosclerosis. Circulation 2003;107:1237-1239. [PubMed: 12628940]

66. Hauer AD, Habets KL, van Wanrooij EJ, et al. Vaccination against TIE2 reduces atherosclerosis. Atherosclerosis 2009;204:365-367. [PubMed: 19022447]

67. Fernández-Hernando C, Ackah E, Yu J, et al. Loss of Akt1 leads to severe atherosclerosis and occlusive coronary artery disease. Cell Metab 2007;6:446-457. [PubMed: 18054314]

68. Duda DG, Fukumura D, Jain RK. Role of eNOS in neovascularization: NO for endothelial progenitor cells. Trends Mol Med 2004;10:143-145. [PubMed: 15162796]

69. Post S, Peeters W, Busser E, et al. Balance between angiopoietin-1 and angiopoietin-2 is in favor of angiopoietin-2 in atherosclerotic plaques with high microvessel density. J Vasc Res 2008;45:244-250. [PubMed: 18182823]

70. Chong AY, Caine GJ, Freestone B, Blann AD, Lip GY. Plasma angiopoietin-1, angiopoietin-2, and angiopoietin receptor tie-2 levels in congestive heart failure. J Am Coll Cardiol 2004;43:423-428. [PubMed: 15013125]

71. Freestone B, Chong AY, Lim HS, Blann A, Lip GY. Angiogenic factors in atrial fibrillation: a possible role in thrombogenesis? Ann Med 2005;38:365-372. [PubMed: 16179272]

72. Kümpers P, Lukasz A, David S, et al. Excess circulating angiopoietin-2 is a strong predictor of mortality in critically ill medical patients. Crit Care 2008;12:R147. [PubMed: 19025590]

73. Helfrich I, Edler L, Sucker A, et al. Angiopoietin-2 levels are associated with disease progression in metastatic malignant melanoma. Clin Cancer Res 2009;15:1384-1392. [PubMed: 19228739]

74. Patel JV, Hoong SL, Varughese G, Hughes E, Lip GYH. Angiopoietin-2 levels as a biomarker of cardiovascular risk in patients with hypertension. Ann Med 2008;40:215-222. [PubMed: 18382887]

75. Virmani R, Kolodgie FD, Burke AP, et al. Atherosclerotic plaque progression and vulnerability to rupture: angiogenesis as a source of intraplaque hemorrhage. Aterioscler Thromb Vasc Biol 2005;25:2054-2061.

76. Roviezzo F, Tsigkos S, Kotanidou A, et al. Angiopoietin-2 causes inflammation in vivo by promoting vascular leakage. J Pharmacol Exp Ther 2005;314:738-744. [PubMed: 15870388]

77. Abdel-Malak NA, Mofarrahi M, Mayaki D, Khachigian LM, Hussain SN. Early growth response-1 regulates angiopoietin-1-induced endothelial cell proliferation, migration, and differentiation. Arterioscler Thromb Vasc Biol 2009;29:209-216. [PubMed: 19112164] 
78. Papapetropoulos A, Fulton D, Mahboubi K, et al. Angiopoietin-1 inhibits endothelial cell apoptosis via the Akt/survivin pathway. J Biol Chem 2000;275:9102-9105. [PubMed: 10734041]

79. Kim I, Kim JH, Moon SO, et al. Angiopoietin-2 at high concentration can enhance endothelial cell survival through the phosphatidylinositol 3'-kinase/Akt signal transduction pathway. Oncogene 2000;19:4549-4552. [PubMed: 11002428]

80. Harfouche R, Hussain SNA. Signaling and regulation of endothelial cell survival by angiopoietin-2. Am J Physiol Heart Circ Physiol 2006;291:H1635-H1645. [PubMed: 16714355]

81. Choke E, Cockerill GW, Dawson J, et al. Increased angiogenesis at the site of abdominal aortic aneurysm rupture. Ann N Y Acad Sci 2006;1085:315-319. [PubMed: 17182949]

82. Sturn DH, Feistritzer C, Mosheimer BA, et al. Angiopoietin affects neutrophil migration. Microcirculation 2005;12:393-403. [PubMed: 16020388]

83. Feistritzer C, Mosheimer BA, Sturn DH, et al. Expression and function of the angiopoietin receptor Tie-2 in human eosinophils. J Allergy Clin Immunol 2004;114:1077-1084. [PubMed: 15536413]

84. Lim HS, Blann AD, Chong AY, Freestone B, Lip GY. Plasma vascular endothelial growth factor, angiopoietin-1, and angiopoietin-2 in diabetes: implications for cardiovascular risk and effects of multifactorial intervention. Diabetes Care 2004;27:1924-2918.

85. David S, Kümpers P, Lukasz A, et al. Circulating angiopoietin-2 in essential hypertension: relation to atherosclerosis, vascular inflammation, and treatment with olmesartan/pravastatin. J Hypertens 2009;27:1641-1647. [PubMed: 19390459] 


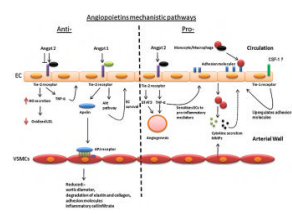

Fig. 1.

Summary of the potential ways in which angpt 1 and 2 may modulate AAA and atherosclerosis and the mechanisms that might be involved in the angpts/Tie signalling cascade. 
Table 1

Summary of the effects of angpts and Tie receptor deficiencies in mice.

\begin{tabular}{ll}
\hline Tie-1 & Tie-2 \\
\hline $\begin{array}{l}\text { Single knockout } \\
\text { Died around E18.5. }\end{array}$ & $\begin{array}{l}\text { Died around E10.5. } \\
\text { Defects in vasculogenesis. } \\
\text { Critical for the survival and proliferation of ECs but not their initial } \\
\text { formation [21,22]. }\end{array}$ \\
$\begin{array}{l}\text { Double knockout } \\
\text { Abnormal vessel structure during embryogenesis [22]. }\end{array}$ & Angpt 2 \\
$\begin{array}{l}\text { Angpt 1 } \\
\text { Single knockout }\end{array}$ & \\
$\begin{array}{l}\text { Angiogenic defects reminiscent of those seen in the Tie-2 } \\
\text { deficient mice embryos [9]. }\end{array}$ & $\begin{array}{l}\text { Required for angiogenesis and lymphatic patterning. } \\
\text { Dependent on the genetic background of the mice [23]. }\end{array}$ \\
\hline
\end{tabular}


Table 2

Summary of the pathological characteristics of athero-thrombosis and aneurysm and the relevance of angpts.

\begin{tabular}{|c|c|c|c|}
\hline Stages of development & Histological feature & Pathological mechanisms & Relevance to angpts \\
\hline \multicolumn{4}{|l|}{ Atherosclerosis } \\
\hline Initiation & Fatty streak & Endothelial injury, inflammation & $\begin{array}{l}\text { Angpt } 2 \text { promotes while angpt } 1 \text { inhibits endothelial } \\
\text { activation to a pro-inflammatory phenotype [37]. }\end{array}$ \\
\hline Progression & Plaque stability & Advanced atherosclerotic plaque & $\begin{array}{l}\text { Upregulation of angpt } 2 \text { inhibits atherosclerosis } \\
\text { development in low-density receptor deficient mice } \\
\text { by promoting nitric oxide inhibition of LDL } \\
\text { oxidation [60]. }\end{array}$ \\
\hline Complications & Plaque rupture & Angiogenesis & $\begin{array}{l}\text { Mice vaccinated against Tie- } 2 \text { demonstrated a more } \\
\text { stable phenotype and an increase in collagen } \\
\text { content [66]. Angpt } 2 \text { has been shown to activate } \\
\text { Tie- } 2 \text { and stably interact with STAT } 5 \text { to potentially } \\
\text { promote neoangiogenesis in advanced } \\
\text { atherosclerosis [37]. Angiogenesis has been } \\
\text { associated with plaque rupture [75]. Angpt } 2 \text { is } \\
\text { associated with increased MMP-2 levels and can } \\
\text { potentially promote unstable plaques with high } \\
\text { microvessel density (MVD) [69]. }\end{array}$ \\
\hline \multicolumn{4}{|l|}{ AAA } \\
\hline Initiation & Dilation & $\begin{array}{l}\text { Elastin and collagen degradation, } \\
\text { inflammation }\end{array}$ & $\begin{array}{l}\text { Angpt } 1 \text { upregulates the expression of apelin which } \\
\text { has been shown to reduce aortic diameter, and } \\
\text { preserve aortic elastin and collagen. Angpt } 1 \\
\text { promotes downregulation of adhesion molecules } \\
\text { inhibits inflammatory cell infiltrate [62]. Angpt } 2 \\
\text { promotes inflammation by favouring vascular } \\
\text { leakage by disrupting cell-cell junctions [76]. }\end{array}$ \\
\hline Progression & $\begin{array}{l}\text { Continued } \\
\text { extracellular matrix } \\
\text { destruction }\end{array}$ & $\begin{array}{l}\text { Angiogenesis and factors } \\
\text { important in initiation }\end{array}$ & $\begin{array}{l}\text { Angpt } 1 \text { promotes angiogenesis by increasing EC } \\
\text { proliferation and inhibiting EC apoptosis }[77,78] \text {. } \\
\text { Angpt } 2 \text { can promote both EC survival and } \\
\text { apoptosis depending on VEGF concentrations } \\
{[17,79,80] \text {. }}\end{array}$ \\
\hline Rupture & $\begin{array}{l}\text { Aortic medial and } \\
\text { adventitia tear }\end{array}$ & Angiogenesis & $\begin{array}{l}\text { Increased medial neovascularization and } \\
\text { overexpression of proangiogenic cytokines have } \\
\text { been reported at the aneurysm rupture edge [81]. }\end{array}$ \\
\hline
\end{tabular}


Table 3

Summary of the potential pro and anti-athero-thrombosis and AAA roles that the angpts play.

\begin{tabular}{|c|c|c|}
\hline Angpts & Pro-athero-thrombosis and AAA & Anti-athero-thrombosis and AAA \\
\hline \multicolumn{3}{|c|}{ Inflammation } \\
\hline Angpt 2 & $\begin{array}{l}\text { Chemoattractant for Tie- } 2 \text { monocytes [55]. Angpt } 2^{-l-} \text { mice showed an inability } \\
\text { to mount an inflammatory response, a phenotype that was rescued upon rAngpt } \\
2 \text { administration [54]. The same affect was seen when sTie- } 2 \text { was administered } \\
\text { to mice. Facilitates the translocation of adhesion molecules in ECs [47]. } \\
\text { Activate ECs and neutrophils [59]. }\end{array}$ & \\
\hline Angpt 1 & Activate ECs and neutrophils [59]. & $\begin{array}{l}\text { Reduces VEGF induction of adhesion } \\
\text { molecules on ECs }[82,83] \text {. }\end{array}$ \\
\hline \multicolumn{3}{|c|}{ Angiogenesis } \\
\hline Angpt 2 & Increases angiogenesis when co-expressed with VEGF [17]. & \\
\hline
\end{tabular}


Table 4

Summary of the case-control studies which have compared circulating levels of angpts and sTie in patients with or without CVD.

\begin{tabular}{|c|c|c|}
\hline Human study & Number & Results of study \\
\hline $\begin{array}{l}\text { Cardiovascular risk in patients with } \\
\text { hypertension [74] }\end{array}$ & $\begin{array}{l}251 \text { Hypertensive } 192 \\
\text { No previous CVD }\end{array}$ & $\begin{array}{l}\text { Patients with hypertension had higher concentrations of plasma angpt } 2 \text { that } \\
\text { were predictive of myocardial infarction (MI). }\end{array}$ \\
\hline Patients with atrial fibrillation [71] & 40 Control 59 Diseased & $\begin{array}{l}\text { Concentrations of plasma angpt } 2 \text { correlated with von Willebrand factor } \\
\text { (vWF). }\end{array}$ \\
\hline $\begin{array}{l}\text { Patients with type } 2 \text { diabetes with or } \\
\text { without CVD [84] }\end{array}$ & 34 Control 38 Diseased & $\begin{array}{l}\text { Increased concentrations of plasma angpt } 2 \text { but not angpt } 1 \text { where detected } \\
\text { in patients with diabetes. Patients who received intensified diabetes } \\
\text { management had a reduction of plasma angpt } 2 \text { if CVD was absent but not } \\
\text { in the presence of CVD. }\end{array}$ \\
\hline $\begin{array}{l}\text { Patients with peripheral arterial } \\
\text { disease (PAD) [35] }\end{array}$ & 23 Control 46 Diseased & Levels of sTie- 2 and angpt 2 in plasma were elevated in patients with PAD \\
\hline $\begin{array}{l}\text { Patients with acute and chronic } \\
\text { congestive heart failure (CHF) [70] }\end{array}$ & $\begin{array}{l}17 \text { Control } 40 \text { Chronic } \\
\text { CHF } 39 \text { Acute CHF }\end{array}$ & $\begin{array}{l}\text { Patients with acute CHF had higher concentrations of angpt } 2 \text { and sTie- } 2 \text { in } \\
\text { plasma, compared to controls and patients with chronic CHF. }\end{array}$ \\
\hline $\begin{array}{l}\text { Hypertensive patients treated with } \\
\text { angiotensin II receptor blockers } \\
\text { (ARB) olmesartan or a placebo. } \\
\text { Pravastatin was also assessed [85] }\end{array}$ & 96 Control 94 Treated & $\begin{array}{l}\text { Angpt } 2 \text { concentrations in plasma were elevated in hypertensive patients, } \\
\text { particularly in women, elderly and in the presence of atherosclerosis. The } \\
\text { elevated angpt } 2 \text { levels in hypertensive patients correlated with adhesion } \\
\text { molecules and inflammation. ARBs effectively decreased several } \\
\text { inflammatory mediators but did not have an effect on angpt } 2 \text { levels. } \\
\text { Pravastatin administration did not reduce angpt } 2 \text { levels. }\end{array}$ \\
\hline
\end{tabular}

